3 Research Square

\title{
Per-head cost of patients responding to eltrombopag and rituximab in the treatment of primary immune thrombocytopenia in Spain.
}

José Ramón Gonzalez-Porras

Hospital Universitario de Salamanca, IBSAL

Francisco Javier Parrondo-García

JParrondoHeath

Eduardo Anguita ( $\nabla$ eduardo.anguita@salud.madrid.org )

Hospital Clínico San Carlos, IdISSC, UCM https://orcid.org/0000-0003-1386-4943

Research article

Keywords: Immune thrombocytopenia, thrombopoietin receptor agonists, eltrombopag, rituximab, cost, financial analysis

Posted Date: April 8th, 2020

DOI: https://doi.org/10.21203/rs.2.19046/v3

License: (c) (i) This work is licensed under a Creative Commons Attribution 4.0 International License. Read Full License 


\section{Abstract}

Background: Splenectomy, thrombopoietin receptor agonists (TPO-RAs) and rituximab are the second-line treatments for steroid-resistant adult primary immune thrombocytopenia (ITP). The last two are becoming the most widely used treatments to avoid splenectomy adverse effects and inconveniences. However, the choice between rituximab and TPO-RAs is unclear. Therefore, the treatment cost may be of particular interest to prioritize the therapy option.

Our aim is to determine the cost per patient after 6 months of treatment of rituximab compared to TPO-RA eltrombopag in a European Health Service.

Methods: A 26-week decision tree model was developed to assess the cost of treatment response of adult patients with chronic-refractory ITP to eltrombopag and rixutimab from the perspective of the Spanish National Health System. Effectiveness was obtained from the literature, and cost was obtained from the official rates. Costs were expressed in $€$ (2018). Due to the short period of assessment, no discount rate was applied.

Results: The average cost per patient after 6 months of treatment was similar for eltrombopag and rituximab, although the first cost was slightly higher. However, the greater response rate of eltrombopag decreases the bleeding costs, resulting in a $29 \%$ higher cost with rituximab treatment. Eltrombopag cost was always lower, except in the sensitivity analysis in which the patient received a daily dose of $75 \mathrm{mg}$ of eltrombopag, a scenario where eltrombopag cost is $48 €$ higher than that of rituximab.

Conclusions: The treatment cost of rituximab, including monitoring and bleeding costs, is higher than eltrombopag, favouring the latter over rituximab treatment.

\section{Background}

Primary immune thrombocytopenia (ITP) is an acquired autoimmune disease characterized by a platelet count less than $100 \times 10^{9}$ platelets/litre; this is due to platelet destruction and inadequate production $[1,2]$. Diagnosis is reached by exclusion of other diseases associated with thrombocytopenia. The annual ITP incidence rate is 3-4/100000 in adults, increasing in older patients [3-5]. This condition is classified as newly diagnosed ITP when the evolution is shorter than 3 months from diagnosis, persistent if the duration of disease is 3-12 months and chronic when it lasts for more than 12 months [1]. Although $1 / 3$ of affected persons are asymptomatic and patients with a platelet count over $50 \times 10^{9}$ platelets/litre do not require treatment, this long-lasting disease may threaten life due to bleeding caused by thrombocytopenia; it negatively impacts quality of life and imparts a high economic burden on the healthcare system $[1,2,6]$.

Classical guidelines recommended corticosteroids as first-line treatment for adult ITP followed by splenectomy as second-line treatment and the use of the anti-CD20 chimeric monoclonal antibody rituximab or a thrombopoietin receptor agonist (TPO-RA) in cases of failure or contraindication $[2,7,8]$.

Splenectomy achieves a $60 \%$ response after 5 years [9]. However, this treatment produces important adverse effects mainly derived from surgery, as well as risk of infection, thrombosis and cancer [10]. In contrast, 
rituximab and TPO-RAs cause few toxicities and spare a splenectomy. The first option permits lasting responses after a short treatment, with approximately $60 \%$ initial responses and a third of patients in remission after 1 year [11-16]. The second involves long-term treatments, but with high response rates (75$95 \%)$, and it has fewer side effects than rituximab and the potential of drug discontinuation [11, 17-22]. Hence, those formerly considered third-line treatments have become extensively used [23]. In fact, the last recommendations indicate that, even if corticoids remain at the first-line treatment, in view of the lack of randomized trials directly comparing splenectomy, rituximab and TPO-RAs, all three can be used as secondline options [11].

TPO-RAs, including eltrombopag and romiplostim, stimulate platelet production, increasing platelet count $[18,24]$. Unlike romiplostim subcutaneous administration, eltrombopag oral administration requires no sanitary assistance [25].

The aim of this paper is to provide data for clinical decisions according to their economic implications through the per-head cost of responding patients to oral TPO-RA eltrombopag and rituximab for treating chronic ITP in the context of the Spanish Health Service.

\section{Methods}

\section{Model}

We have developed a cost-consequence model to compare the direct health costs of ITP treatment with eltrombopag and rixutimab from the perspective of Spanish public hospitals. As in a similar study comparing romiplostim and rituximab [27], only direct hospital health costs of patients treated with eltrombopag and rituximab were considered. Grade 1 (petechial) bleedings, which are treated by the patients themselves or at the primary care services, were not considered.

To allow the comparison with a similar study that evaluated the cost per response of romiplostim and rituximab [27], a time horizon of 26 weeks (half a year) was set. As shown in Figure 1, it was split into two periods. The first one comprised 8 weeks during which all patients were treated, and the response was evaluated. This was followed by a period of 18 weeks in which a) only patients responding to eltrombopag continued to be treated and $b$ ) patients on rituximab were treated according to previously described bases [26]. This structure is coherent with the previously mentioned study carried out in Spain [27], so it may support decision-making.

As the time horizon is less than a year, we did not consider applying discounting to costs or effects.

In this way, over the 26 weeks, the model accumulates treatment costs (drugs plus administration), follow-up costs and the costs produced by bleedings to calculate the final cost per responding patient to both treatment alternatives.

\section{Study population}


Considering that eltrombopag is indicated for patients of more than one year of age with chronic ITP who are refractory to other treatments [25] and that although rituximab is not officially approved for this disease, it is indicated for adult patients in the illnesses in which it is approved [28], we have limited our analysis to adults with chronic-refractory ITP.

To determine the effectiveness of these treatments, we carried out a literature review of chronic ITP treatment published in English and Spanish between 2000 and 2017. As a result, we have identified a paper focused on a group of Spanish patients treated with eltrombopag [29]. As no similar paper has been found for rituximab (on Spanish patients with chronic-refractory ITP), we have used the data from the Arnold DM et al systematic review [32].

To estimate rituximab dosage, we used the Dubois \& Dubois formula to determine the body surface of patients [30]. Height and weight were determined according to microdata from the Spanish results of the European Health Survey 2014 (basal data shown in Table 1) [31].

\section{Estimate of response}

No study or phase 3 clinical trial related to rituximab response was found in Spain; therefore, the more consistent data for this treatment derive from the indicated systematic review [32]. Additionally, we used a retrospective French model to evaluate the need for re-treatment and its effectiveness [26].

Table 2 shows the response rates used in the model, their sources and the criteria employed to evaluate the response. The re-treatment rates and their responses are shown in Table 3.

As Table 2 shows, there are differences in the response criteria. While the eltrombopag study used the full response rate (defined as platelet count ${ }^{3} 100 \times 10^{9} /$ I) and the response rate (platelet count ${ }^{3} 30$ and $<100$ ), the rituximab study used a different response rate (defined as platelet count ${ }^{3} 50 \times 10^{9} / \mathrm{I}$ ). Despite this, a superior efficacy of eltrombopag against rituximab can be established, since its complete response rate is $77.3 \%$, while the rituximab response rate is $62.5 \%$.

\section{Bleeding estimate}

As petechial bleeding does not involve hospital attention-it is cared for at primary care services-the model only considers 2-, 3- and 4-grade bleeding (WHO bleeding scale [33], Additional file 1).

There is a relationship between a low platelet count and an increased risk of bleeding. In this way, patients who do not respond to treatment will have a lower count and an increased risk of bleeding than responding patients. To simulate these bleeding risks, we have used the RAISE trial data [19], assuming that nonresponding patients behave in the same way as the placebo arm in relation to the risk of bleeding while responding patients present a similar risk decrease to that in the treatment arm of the trial.

This assumption seems to be valid considering the effectiveness of eltrombopag and the duration of this trial, which is equivalent to that of the model (six months). The bleeding rates used in the model are shown 
in Table 4. Grade 4 bleedings are potentially life threatening, with a mortality rate of $40 \%$; $80 \%$ of patients who survive after such bleeding need rehabilitation [34].

\section{Resources and costs}

To make a cost estimation, we used an average of the official lists of prices of the different Spanish regions (Additional file 2. Prices are actualized to 2018 euro (€2018).

As both alternatives are hospital formulary drugs, prices to wholesalers have been used, thus avoiding the extra costs involved by distribution channels and chemist stores.

Table 5 shows the price to wholesale (PTW) of the different drugs as they appear in BotPlusWeb Portalfarma (online drugs database of the General Council of Official Pharmaceutical Associations, https://botplusweb.portalfarma.com, accessed 1 June 2018).

To calculate the cost of the drugs, we considered the cost per mg and applied it to doses as described in the trials. Each rituximab treatment comprises 4 cycles of $375 \mathrm{mg}$ for each square metre of body surface [32], implying a daily dose of $25 \mathrm{mg}$ for $17.13 \%$ of the patients, a dose of $50 \mathrm{mg}$ for $40.89 \%$ and a dose of $75 \mathrm{mg}$ for $41.98 \%$ [19]. In the case of rituximab, an extra administration cost must be added; as the drug is administered in the hospital, we have assumed it is equivalent to day-hospital costs.

Table 6 shows the costs and their use in the model. Eltrombopag response is monitored weekly during the first 8 weeks and then once a month after week 8 . For rituximab, monitoring is carried out weekly for the first 4 weeks and once a month after that. We assumed that a grade 2 bleeding cost is 0.6 times the cost of a specialist consultation plus 0.3 times the cost of an urgency consultation. For grade 3 bleedings, we assumed a diagnosis-related group (DRG) 174 (gastrointestinal bleeding) cost; for grade 4 bleedings, we assumed a cost of 0.2 times DRG 810 (medical intracranial haemorrhage) plus 0.8 times the cost of DRG 833 (surgical intracranial haemorrhage) and the cost of rehabilitation when applying. This rehabilitation process after grade 4 bleeding, when needed, was assumed to last 6 months and to include a monthly visit to the physiotherapy consultant, five physiotherapy and speech therapy sessions every week and three weekly occupational therapy sessions [35].

\section{Sensitivity analysis}

To analyse the effect of the different variables on the model results, we carried out 15 sensitivity analyses, described in Table 7.

\section{Results}

The average cost per patient after a 6-month treatment was $13089.40 €$ for eltrombopag and $11852.60 €$ for rituximab. Itemised costs show that the greater response rate of the first involves a decrease in bleeding costs (811.27€ with rituximab, 499.97€ with eltrombopag). Due to the lower efficacy of rituximab, the average cost of response is $14732.65 €$ with eltrombopag and $18964.15 €$ with rituximab $(29 \%$ higher with the latter). 
Tables 8,9 and 10 show the base case and sensitivity analysis results. The cost of eltrombopag is always lower, excluding the sensitivity analysis in which the patient received a daily dose of $75 \mathrm{mg}$ of eltrombopag - a scenario where eltrombopag global cost is $5039.58 €$ over rituximab, but when response cost is considered, the difference is reduced to only $48 €$ higher than that of rituximab.

\section{Discussion}

Patient refusal and hazards derived from surgery plus lifelong increased risk of infection, thromboembolic events and malignancy after splenectomy have increased the use of TPO-RAs and rituximab [36, 37]. The last American Hematology Association guideline for ITP treatment update recommends rituximab over splenectomy and places splenectomy and TPO-RAs at the same level. The preference between rituximab and TPO-RAs is under discussion in unresponsive to steroids or persistent ITP [11]. Hence, the cost and effectiveness of both types of treatment must be carefully evaluated to make appropriate medical decisions. We selected TPO-RA eltrombopag for this study over romiplostim due to its oral, out-of-hospital administration, in contrast to the subcutaneous administration of romiplostim, which needs sanitary assistance.

Here, we show that the cost of a 6-month treatment is similar using rituximab and eltrombopag, $13089.40 €$ and $11852.60 €$, respectively. Both treatments accomplish responses and have low side effects, but lower beneficial effects have been observed with rituximab [23]. Therefore, as the response to treatment with eltrombopag is greater, the cost per-responding patient is smaller, even though the treatment cost itself is higher, turning the budget to $14732.65 €$ for eltrombopag and $18964.15 €$ for rituximab in that period of time. These results are indirectly consistent with those from other economic evaluations in Spain showing that eltrombopag was cost-effective against romiplostim and romiplostim was cost-effective against rituximab $[27,35]$. Additionally, a recent meta-analysis indirectly comparing rituximab and TPO-RAs eltrombopag and romiplostim treatment for persistent or chronic ITP suggests that the second type of treatment is superior to the former when considering response (platelet $\geq 50 \times 10^{9} / \mathrm{L}$ ), clinically significant and severe bleeding [38]. Additionally, although treatment with eltrombopag is considered chronic, there is evidence that suggests that it is possible to discontinue the treatment [29].

Another issue to consider is that the rituximab administration route is intravenous or subcutaneous after the first dose, and it has to be monitored at the hospital for undesired side effects versus oral administration at home in the case of eltrombopag. Therefore, treatment with eltrombopag lessens the workload at day hospitals, allowing resources to be focused on other patients who need day-hospital facilities for the administration of their treatments (such as chemotherapy). A limitation of this study is that the model does not take into account the adverse effects caused by treatments, which may potentially be more severe in the first perfusions of the monoclonal antibody than in the case of the receptor agonist thrombopoietin.

As data for rituximab do not inform of splenectomised patients, our model considers the Spanish average of $22 \%$ splenectomised patients, but it cannot itemise the splenectomised group of patients. Clinical studies have shown that eltrombopag is more effective in non-splenectomised patients [19, 39, 40], so an increase in the number of splenectomised patients could mean a decrease in the response rate. 
A final limitation is related to the use of rituximab at a lower dose $(100 \mathrm{mg})$. In the absence of efficacy data at this dose, this option has not been considered for the present analysis (it should be noted that the use of data that are not sufficiently comprehensible would in turn imply another limitation). Additionally, using a standard dose of rituximab of $375 \mathrm{mg}$ is consistent with a similar article in which rituximab was evaluated against romiplostim [27] and may allow comparison between both.

\section{Conclusions}

The treatment budget of rituximab, considering monitoring and bleeding costs, is higher than that of eltrombopag. This, together with long response rates and the reduced undesirable effects, supports the recommendation of the latter treatment over rituximab. This type of analysis should be required to guide healthcare policies and treatment decision-making.

\section{List Of Abbreviations}

Cl: Confidence interval

CR: Complete response

DRG: Diagnosis-related group

EHIS: European Health Interview Survey

IC: Intracranial

ITP: Primary immune thrombocytopenia

GI: Gastrointestinal

Ref: Reference

SA: Sensitivity analysis

TPO-RAs: Thrombopoietin receptor agonists

WHO: World Health Organization

\section{Declarations}

\section{Ethics approval and consent to participate}

Not applicable

\section{Consent to publish}

Not applicable 


\section{Availability of data and materials}

All data generated or analysed during this study are included in this published article, its supplementary information files and references.

\section{Competing interests}

JRG-P has received fees for consulting services by Amgen, Novartis, SOBI, Grifols and CSL Behring and speaking honoraria from Novonordisk, Shire, SOBI, Roche, Daiichi Sankyo, Pfizer, Rovi, Amgen, and Novartis. EA has received speaking honoraria and support for attending conferences from Amgen and Novartis.

\section{Funding}

Hay Esperanza Foundation contributed to publishing expenses.

\section{Authors' contributions}

FJP-G performed the data analysis. EA, JRG-P, and FJP-G designed the study, wrote the paper and participated in the interpretation of data as well as in the critical revision of the manuscript.

All authors have read and approved the manuscript.

\section{Acknowledgements}

Not applicable.

\section{References}

1. Rodeghiero F, Stasi R, Gernsheimer T, Michel M, Provan D, Arnold DM, Bussel JB, Cines DB, Chong BH, Cooper N, Godeau B, Lechner K, Mazzucconi MG, McMillan R, Sanz MA, Imbach P, Blanchette V, Kühne T, Ruggeri M, George JN. Standardization of terminology, definitions and outcome criteria in immune thrombocytopenic purpura of adults and children: report from an international working group. Blood. 2009;113:2386-93. https://doi.org/10.1182/blood-2008-07-162503.

2. Sanz MA, Vicente Garcia V, Fernandez A, Lopez MF, Grande C, Jarque I, Martínez R, Mingot ME, Monteagudo E, Ribera JM, Valcárcel D. [Guidelines for diagnosis, treatment and monitoring of primary immune thrombocytopenia]. Med Clin (Barc). 2012; 138:261.e1-261.e17. https://doi.org/10.1016/j.medcli.2011.11.011.

3. Schoonen WM, Kucera G, Coalson J, Li L, Rutstein M, Mowat F, Fryzek J, Kaye JA. Epidemiology of immune thrombocytopenic purpura in the General Practice Research Database. Br J Haematol. 2009;145:235-44. https://doi.org/10.1111/j.1365-2141.2009.07615.x.

4. Terrell DR, Beebe LA, Vesely SK, Neas BR, Segal JB, George JN. The incidence of immune thrombocytopenic purpura in children and adults: A critical review of published reports. Am $\mathrm{J}$ Hematol. 2010;85:174-80. https://doi.org/10.1002/ajh.21616. 
5. Moulis G, Lapeyre-Mestre M, Mahévas M, Montastruc JL, Sailler L. Need for an improved vaccination rate in primary immune thrombocytopenia patients exposed to rituximab or splenectomy. A nationwide population-based study in France. Am J Hematol. 2015;90:301-5. https://doi.org/10.1002/ajh.23930.

6. Saleh MN, Fisher M, Grotzinger KM. Analysis of the impact and burden of illness of adult chronic ITP in the US. Curr Med Res Opin. 2009;25:2961-9. https://doi.org/10.1185/03007990903362388.

7. Neunert C, Lim W, Crowther M, Cohen A, Solberg L Jr, Crowther MA. The American Society of Hematology 2011 evidence-based practice guideline for immune thrombocytopenia. 2011;117:4190207. https://doi.org/10.1182/blood-2010-08-302984.

8. Rodeghiero F, Ruggeri M. ITP and international guidelines: what do we know, what do we need? Presse Med. 2014;43:e61-7. https://doi.org/10.1016/j.lpm.2014.02.004.

9. Kahn MJ, McCrae KR. Splenectomy in immune thrombocytopenic purpura: recent controversies and long-term outcomes. Curr Hematol Rep. 2004:3:317-23.

10. Rubin LG, Schaffner W. Clinical practice. Care of the asplenic patient. N Engl J Med. 2014;371:349-56. https://doi.org/10.1056/NEJMcp1314291.

11. Neunert CE, Cooper N. Evidence-based management of immune thrombocytopenia: ASH guideline update. Hematology Am Soc Hematol Educ Program. 2018;2018:568-75. https://doi.org/1182/asheducation-2018.1.568.

12. Cooper N, Stasi R, Cunningham-Rundles S, Feuerstein MA, Leonard JP, Amadori S, Bussel JB. The efficacy and safety of B-cell depletion with anti-CD20 monoclonal antibody in adults with chronic immune thrombocytopenic purpura. Br J Haematol. 2004;125:232-9. https://doi.org/10.1111/j.13652141.2004.04889.x.

13. Godeau B, Porcher R, Fain O, Lefrère F, Fenaux P, Cheze S, Vekhoff A, Chauveheid MP, Stirnemann J, Galicier L, Bourgeois E, Haiat S, Varet B, Leporrier M, Papo T, Khellaf M, Michel M, Bierling P. Rituximab efficacy and safety in adult splenectomy candidates with chronic immune thrombocytopenic purpura: results of a prospective multicenter phase 2 study. 2008;112:999-1004. https://doi.org/10.1182/blood2008-01-131029.

14. Khellaf M, Charles-Nelson A, Fain O, Terriou L, Viallard JF, Cheze S, Graveleau J, Slama B, Audia S, Ebbo M, Le Guenno G, Cliquennois M, Salles G, Bonmati C, Teillet F, Galicier L, Hot A, Lambotte O, Lefrère F, Sacko S, Kengue DK, Bierling P, Roudot-Thoraval F, Michel M, Godeau B. Safety and efficacy of rituximab in adult immune thrombocytopenia: results from a prospective registry including 248 patients. 2014;124:3228-3236. https://doi.org/10.1182/blood-2014-06-582346.

15. Tran H, Brighton T, Grigg A, McRae S, Dixon J, Thurley D, Gandhi MK, Truman M, Marlton P, Catalano J. A multi-centre, single-arm, open-label study evaluating the safety and efficacy of fixed dose rituximab in patients with refractory, relapsed or chronic idiopathic thrombocytopenic purpura (R-ITP1000 study). Br J Haematol. 2014;167:243-251. https://doi.org/10.1111/bjh.13029.

16. Ghanima W, Khelif A, Waage A, Michel M, Tjønnfjord GE, Romdhan NB, Kahrs J, Darne B, Holme PA. Rituximab as second-line treatment for adult immune thrombocytopenia (the RITP trial): a multicentre, randomised, double-blind, placebo-controlled trial. Lancet. 2015;385:1653-61. https://doi.org/10.1016/S0140-6736(14)61495-1. 
17. Gonzalez-Porras JR, Bastida JM. Eltrombopag in immune thrombocytopenia: efficacy review and update on drug safety. Ther Adv Drug Saf. 2018;9:263-85. https://doi.org/10.1177/2042098618769587.

18. Bussel JB, Cheng G, Saleh MN, Psaila B, Kovaleva L, Meddeb B, Kloczko J, Hassani H, Mayer B, Stone $\mathrm{NL}$, Arning M, Provan D, Jenkins JM. Eltrombopag for the treatment of chronic idiopathic thrombocytopenic purpura. N Engl J Med. 2007;357:2237-47. https://doi.org/10.1056/NEJMoa073275.

19. Cheng G, Saleh MN, Marcher C, Vasey S, Mayer B, Aivado M, Arning M, Stone NL, Bussel JB. Eltrombopag for management of chronic immune thrombocytopenia (RAISE): a 6-month, randomised, phase 3 study. Lancet. 2011;377:393-402. https://doi.org/10.1016/S0140-6736(10)60959-2.

20. Grainger JD, Locatelli F, Chotsampancharoen T, Donyush E, Pongtanakul B, Komvilaisak P, Sosothikul D, Drelichman G, Sirachainan N, Holzhauer S, Lebedev V, Lemons R, Pospisilova D, Ramenghi U, Bussel JB, Bakshi KK, lyengar M, Chan GW, Chagin KD, Theodore D, Marcello LM, Bailey CK. Eltrombopag for children with chronic immune thrombocytopenia (PETIT2): a randomised, multicentre, placebocontrolled trial. 2015;386:1649-1658. https://doi.org/10.1016/S0140-6736(15)61107-2.

21. Tarantino MD, Bussel JB, Blanchette VS, Despotovic J, Bennett C, Raj A, Williams B, Beam D, Morales J, Rose MJ, Carpenter N, Nie K, Eisen M. Romiplostim in children with immune thrombocytopenia: a phase 3, randomised, double-blind, placebo-controlled study. 2016;388:45-54. https://doi.org/10.1016/S01406736(16)00279-8.

22. Lucchini E, Fanin R, Cooper N, Zaja F. Management of immune thrombocytopenia in elderly patients. Eur J Intern Med. 2018;58:70-6. https://doi.org/10.1016/j.ejim.2018.09.005.

23. Bylsma LC, Fryzek JP, Cetin K, Callaghan F, Bezold C, Mehta B, Wasser JS. Systematic literature review of treatments used for adult immune thrombocytopenia in the second-line setting. Am J Hematol. 2019;94:118-32. https://doi.org/10.1002/ajh.25301.

24. Bussel JB, Kuter DJ, George JN, McMillan R, Aledort LM, Conklin GT, Lichtin AE, Lyons RM, Nieva J, Wasser JS, Wiznitzer I, Kelly R, Chen CF, Nichol JL. AMG 531, a thrombopoiesis-stimulating protein, for chronic ITP. N Engl J Med. 2006;355:1672-1681. https://doi.org/10.1056/NEJMoa054626.

25. Product information of Revolade (eltrombopag). European Medicines Agency. 2018. https://www.ema.europa.eu/en/documents/product-information/revolade-epar-productinformation_en.pdf. Accessed 15 January 2019.

26. Brah S, Chiche L, Fanciullino R, Bornet C, Mancini J, Schleinitz N, Jean R, Kaplanski G, Harlé JR, Durand JM. Efficacy of rituximab in immune thrombocytopenic purpura: a retrospective survey. Ann Hematol. 2012;91:279-85. https://doi.org/10.1007/s00277-011-1283-3.

27. Lopez MF, Mingot ME, Valcarcel D, Vicente Garcia V, Perrin A, Campos Tapias I. [Cost-per-responder analysis comparing romiplostim to rituximab in the treatment of adult primary immune thrombocytopenia in Spain]. Med Clin (Barc). 2015;144:389-96. https://doi.org/10.1016/j.medcli.2013.11.035.

28. Product information of Mabthera (rituximab). European Medicines Agency. https://www.ema.europa.eu/en/documents/product-information/mabthera-epar-productinformation_en.pdf. Accessed 15 January 2019. 
29. Gonzalez-Lopez TJ, Pascual C, Alvarez-Roman MT, Fernandez-Fuertes F, Sanchez-Gonzalez B, Caparros I, Jarque I, Mingot-Castellano ME, Hernández-Rivas JA, Martín-Salces M, Solán L, Beneit P, Jiménez R, Bernat S, Andrade MM, Cortés M, Cortti MJ, Pérez-Crespo S, Gómez-Núñez M, Olivera PE, Pérez-Rus G, Martínez-Robles V, Alonso R, Fernández-Rodríguez A, Arratibel MC, Perera M, Fernández-Miñano C, Fuertes-Palacio MA, Vázquez-Paganini JA, Gutierrez-Jomarrón I, Valcarce I, de Cabo E, Sainz A, Fisac R, Aguilar C, Paz Martínez-Badas M, Peñarrubia MJ, Calbacho M, de Cos C, González-Silva M, Coria E, Alonso A, Casaus A, Luaña A, Galán P, Fernández-Canal C, Garcia-Frade J, González-Porras JR. Successful discontinuation of eltrombopag after complete remission in patients with primary immune thrombocytopenia. Am J Hematol. 2015;90:E40-3. https://doi.org/10.1002/ajh.23900.

30. Dubois D, Dubois EF. A formula to estimate the approximate surface area if height and weight be knonw. Arch Intern Med (Chic). 1916;17:863-871.

31. European Survey of Health in Spain. INE 2014. 2015. http://www.ine.es/dyngs/INEbase/en/operacion.htm? c=Estadistica_C\&cid=1254736176784\&menu=resultados\&secc=1254736195298\&idp=1254735573175. Accessed 1 April 2018.

32. Arnold DM, Dentali F, Crowther MA, Meyer RM, Cook RJ, Sigouin C, Fraser GA, Lim W, Kelton JG. Systematic review: efficacy and safety of rituximab for adults with idiopathic thrombocytopenic purpura. Ann Intern Med. 2007;146:25-33. https://doi.org/10.7326/0003-4819-146-1-200701020-00006

33. Fogarty PF, Tarantino MD, Brainsky A, Signorovitch J, Grotzinger KM. Selective validation of the WHO Bleeding Scale in patients with chronic immune thrombocytopenia. Curr Med Res Opin. 2012;28:79-87. https://doi.org/10.1185/03007995.2011.644849.

34. Cohen YC, Djulbegovic B, Shamai-Lubovitz O, Mozes B. The bleeding risk and natural history of idiopathic thrombocytopenic purpura in patients with persistent low platelet counts. Arch Intern Med. 2000;160:1630-8. https://doi.org/10.1001/archinte.160.11.1630.

35. Parrondo J, Grande C, Ibáñez J, Palau J, Páramo JA, Villa G. [Economic evaluation of Thrombopoietin Receptor Agonists in the treatment of chronic primary immune thrombocytopenia]. Farm Hosp. 2013;37:182-91. https://doi.org/10.7399/FH.2013.37.3.526.

36. Kristinsson SY, Gridley G, Hoover RN, Check D, Landgren O. Long-term risks after splenectomy among 8,149 cancer-free American veterans: a cohort study with up to 27 years follow-up. 2014;99:392-8. https://doi.org/10.3324/haematol.2013.092460.

37. Anguita E, Candel FJ, González-Del Castillo J, Martín-Sánchez FJ. Splenectomy in ITP: we keep removing a healthy functional organ. Ann Hematol. 2016;95:1911-2. https://doi.org/10.1007/s00277-016-2778-8.

38. Arai Y, Matsui H, Jo T, Kondo T, Takaori-Kondo A. Comparison of treatments for persistent/chronic immune thrombocytopenia: a systematic review and network meta-analysis. 2019;30:946-56. doi: 10.1080/09537104.2018.1543864.

39. Mazza P, Minoia C, Melpignano A, Polimeno G, Cascavilla N, Di Renzo N, Specchia G. The use of thrombopoietin-receptor agonists (TPO-RAs) in immune thrombocytopenia (ITP): a "real life" retrospective multicenter experience of the Rete Ematologica Pugliese (REP). Ann Hematol. 2016;95:239-44. https://doi.org/10.1007/s00277-015-2556-z. 
40. González-López TJ, Alvarez-Román MT, Pascual C, Sánchez-González B, Fernández-Fuentes F, Jarque I, Pérez-Rus G, Pérez-Crespo S, Bernat S, Hernández-Rivas JA, Andrade MM, Cortés M, Gómez-Nuñez M, Olivera P, Martínez-Robles V, Fernández-Rodríguez A, Fuertes-Palacio MA, Fernández-Miñano C, de Cabo E, Fisac R, Aguilar C, Bárez A, Peñarrubia MJ, García-Frade LJ, González-Porras JR. Eltrombopag safety and efficacy for primary chronic immune thrombocytopenia in clinical practice. Eur J Haematol. 2016; 97:297-302. https://doi.org/10.1111/ejh.12725.

\section{Tables}

Table 1. Basal characteristics of the population used in the model.

\begin{tabular}{|l|l|l|}
\hline Variable & Value & Reference \\
\hline Sex (women \%) & 63 & Gonzalez-Lopez TJ, et al. 2015 [29]. \\
\hline Average age (years) & 60 & Gonzalez-Lopez TJ, et al. 2015 [29]. \\
\hline $\begin{array}{l}\text { Average women weight } \\
\text { (kg) }\end{array}$ & 65.75 & $\begin{array}{l}\text { European Survey of Health in Spain. INE 2014; 2015 Oct } \\
21 \text { [31]. }\end{array}$ \\
\hline $\begin{array}{l}\text { Average men weight } \\
\text { (kg) }\end{array}$ & 79.90 & $\begin{array}{l}\text { European Survey of Health in Spain. INE 2014; 2015 Oct } \\
21[31] .\end{array}$ \\
\hline $\begin{array}{l}\text { Average women height } \\
(\mathrm{cm})\end{array}$ & 161 & $\begin{array}{l}\text { European Survey of Health in Spain. INE 2014; 2015 Oct } \\
21 \text { [31]. }\end{array}$ \\
\hline $\begin{array}{l}\text { Average men height } \\
(\mathrm{cm})\end{array}$ & 173 & $\begin{array}{l}\text { European Survey of Health in Spain. INE 2014; 2015 Oct } \\
21 \text { [31]. }\end{array}$ \\
\hline
\end{tabular}

Table 2. Response rates according to treatment.

\begin{tabular}{|l|l|l|l|}
\hline $\begin{array}{l}\text { Treatment/kind } \\
\text { response }\end{array}$ & $\begin{array}{l}\text { Response } \\
\text { rate }\end{array}$ & $\begin{array}{l}\text { Response } \\
\text { criteria } \\
\text { (platelets } \\
\left.10^{9} / \mathbf{l}\right)\end{array}$ & Ref. \\
\hline $\begin{array}{l}\text { Eltrombopag/Full } \\
\text { response }\end{array}$ & $77.31 \%$ & $\geq 100$ & $\begin{array}{l}\text { Gonzalez-Lopez TJ, et al. 2015 } \\
{[29] .}\end{array}$ \\
\hline $\begin{array}{l}\text { Eltrombopag/Partial } \\
\text { response }\end{array}$ & $11.54 \%$ & $<100 \& \geq 30$ & $\begin{array}{l}\text { Gonzalez-Lopez TJ, et al. 2015 } \\
{[29] .}\end{array}$ \\
\hline Eltrombopag/No response & $11.15 \%$ & $<30$ & $\begin{array}{l}\text { Gonzalez-Lopez TJ, et al. 2015 } \\
\text { [29]. }\end{array}$ \\
\hline Rituximab/Response & $62.50 \%$ & $\geq 50$ & Arnold DM, et al. 2007 [32]. \\
\hline Rituximab/No response & $37.50 \%$ & $<50$ & Arnold DM, et al. 2007 [32]. \\
\hline
\end{tabular}

Ref, reference. 
Table 3. Re-treatment rates.

Re-treatment/kind of responseBrah S, et al. 2012 [26].

Patients responding to first treatment: eltrombopag

\begin{tabular}{|l|l|}
\hline No re-treatment & $75 \%$ \\
\hline Re-treatment/Partial response & $21.43 \%$ \\
\hline No response & $3.57 \%$ \\
\hline Patients responding to first treatment: rituximab \\
\hline No re-treatment & $63.64 \%$ \\
\hline Response & $27.27 \% \%$ \\
\hline No response & $9.09 \%$ \\
\hline
\end{tabular}

Table 4. Bleeding rates on the basis of response.

\begin{tabular}{|l|l|l|}
\hline Kind of bleeding & Responding patients & Non-responding patients \\
\hline Grade 2 & $13.19 \%$ & $22.95 \%$ \\
\hline Grade 3 & $4.40 \%$ & $14.75 \%$ \\
\hline Grade 4 & $0.55 \%$ & $3.28 \%$ \\
\hline
\end{tabular}

Table 5. Price of drugs used for the model.

\begin{tabular}{|l|l|}
\hline Drug & Price ($(\mathbf{)})$ \\
\hline Eltrombopag 25 mg x 28 pills & 843.62 \\
\hline Eltrombopag 50 mg x 28 pills & 1687.24 \\
\hline Mabthera 100 mg solution x 2 vials & 495.18 \\
\hline Mabthera 500 mg solution x 1 vial & 1234.53 \\
\hline Truxima 100 mg solution x 2 vials & 420.90 \\
\hline Truxima 500 mg solution x 1 vial & 1049.35 \\
\hline
\end{tabular}

Table 6. Costs included in the model. 


\begin{tabular}{|l|l|}
\hline Concept & Cost (€) \\
\hline Specialist consultation & 96.95 \\
\hline Urgency consultation & 234.80 \\
\hline DRG 174 (GI bleeding) & 5015.89 \\
\hline DRG 810 (medical IC haemorrhage) & 7305.87 \\
\hline DRG 833 (surgical IC haemorrhage) & 25515.31 \\
\hline Physiotherapy consultation & 21.46 \\
\hline Speech therapy consultation & 20.65 \\
\hline Occupational therapy consultation & 19.58 \\
\hline Day-hospital consultation & 306.36 \\
\hline 6-month rehabilitation & 4004.46 \\
\hline Costs for calculated event & \\
\hline Bleeding grade 2 & 128.61 \\
\hline Bleeding grade 3 & 5015.89 \\
\hline Bleeding grade 4 & 23795.57 \\
\hline
\end{tabular}

DRG, diagnosis-related group; GI, gastrointestinal; IC, intracranial.

Table 7. List of carried out sensitivity analyses. 


\begin{tabular}{|c|c|}
\hline Analysis & Description \\
\hline $\begin{array}{l}\text { Base } \\
\text { case }\end{array}$ & $\begin{array}{ll}\text {. } & \text { Body surface after EHIS } 2014 \text { data } \\
\text {. } & \text { Eltrombopag dose after RAISE trial ( } 56.21 \mathrm{mg} / \text { day) } \\
\text {. } & \text { Re-treatment with rituximab after retrospective study. } \\
\text {. } & \text { Both full and partial responses to eltrombopag are considered as response } \\
\text {. } & \text { Average value of rituximab efficacy } \\
\text {. } & \text { Rituximab administration cost }(=1 \text { day-hospital consultation) } \\
\text {. } & \text { Monthly monitoring of rituximab after the first } 4 \text { weeks of response } \\
\text {. } & \text { Rituximab, mabthera price }\end{array}$ \\
\hline SA 1 & Body surface $1.70 \mathrm{~m}^{2}$ \\
\hline SA 2 & Eltrombopag dose $50 \mathrm{mg} /$ day \\
\hline SA 3 & Eltrombopag dose $25 \mathrm{mg} /$ day \\
\hline SA 4 & Eltrombopag dose 75 mg/day \\
\hline SA 5 & No re-treatment with rituximab \\
\hline SA 6 & Re-treatment with rituximab only for the responding group. \\
\hline SA 7 & - $\quad$ Re-treatment with rituximab only for the non-responding group. \\
\hline SA 8 & . $\quad$ Only full responses to eltrombopag were considered. \\
\hline SA 9 & $\begin{array}{l}\text { Decrease in rituximab efficacy to the lower threshold of the confidence } \\
\text { interval }\end{array}$ \\
\hline SA 10 & $\begin{array}{l}\text { Increase in rituximab efficacy to the upper threshold of the confidence } \\
\text { interval }\end{array}$ \\
\hline SA 11 & . $\quad$ Rituximab administration cost (=specialist consultation) \\
\hline SA 12 & $\begin{array}{l}\text { Twice-a-month rituximab monitoring after the first } 4 \text { weeks of response } \\
\text { evaluation }\end{array}$ \\
\hline SA 13 & . $10 \%$ decrease in bleeding costs \\
\hline SA 14 & $10 \%$ increase in bleeding costs \\
\hline SA 15 & Rituximab, truxima price \\
\hline
\end{tabular}

EHIS, European Health Interview Survey; SA, sensitivity analysis.

Table 8. Base case and sensitivity analysis results. Per-patient global cost of treatment with eltrombopag and rituximab. 


\begin{tabular}{|c|c|c|c|}
\hline & & \multicolumn{2}{|c|}{ Cost per patient $(€)$} \\
\hline & & Eltrombopag & Rituximab \\
\hline $\begin{array}{l}\text { BASE } \\
\text { CASE }\end{array}$ & & 13089.40 & 11852.60 \\
\hline SA 1 & Body surface & 13089.40 & 11454.77 \\
\hline SA 2 & Eltrombopag dose $25 \mathrm{mg} /$ day & 6771.98 & 11852.60 \\
\hline SA 3 & Eltrombopag dose $50 \mathrm{mg} /$ day & 11832.08 & 11852.60 \\
\hline SA 4 & Eltrombopag dose $75 \mathrm{mg} /$ day & 16892.18 & 11852.60 \\
\hline SA 5 & No re-treatment with rituximab & 13089.40 & 9561.63 \\
\hline SA 6 & $\begin{array}{l}\text { Re-treatment with rituximab only for responding } \\
\text { patients }\end{array}$ & 13089.40 & 10784.96 \\
\hline SA 7 & $\begin{array}{l}\text { Re-treatment with rituximab only for non-responding } \\
\text { patients }\end{array}$ & 13089.40 & 10629.27 \\
\hline SA 8 & Decrease in eltrombopag efficacy (CR patients) & 12240.82 & 11852.60 \\
\hline SA 9 & Rituximab efficacy lower CI threshold & 13089.40 & 12057.65 \\
\hline SA 10 & Rituximab efficacy higher CI threshold & 13089.40 & 11645.47 \\
\hline SA 11 & $\begin{array}{l}\text { Rituximab administration }=\text { specialist consultation } \\
\text { cost }\end{array}$ & 13089.40 & 10769.87 \\
\hline SA 12 & Monitoring decrease in rituximab & 13089.40 & 11537.50 \\
\hline SA 13 & Decrease bleeding costs $(-10 \%)$ & 13039.40 & 11771.47 \\
\hline SA 14 & Increase bleeding costs $(+10 \%)$ & 13139.39 & 11933.72 \\
\hline SA 15 & Rituximab, truxima price & 13089.40 & 10572.16 \\
\hline
\end{tabular}

CI, confidence interval; SA, sensitivity analysis; CR, complete response.

Table 9. Base case and sensitivity analysis results. Itemised costs of per-patient treatment with eltrombopag and rituximab. 


\begin{tabular}{|c|c|c|c|c|c|c|}
\hline & \multicolumn{2}{|c|}{ Treatment costs $(€)$} & \multicolumn{2}{|c|}{ Monitoring costs $(€)$} & \multicolumn{2}{|c|}{ Bleeding costs ( $€$ ) } \\
\hline & Eltrombopag & Rituximab & Eltrombopag & Rituximab & Eltrombopag & Rituximab \\
\hline BASE CASE & 11377.51 & 10120.27 & 1211.91 & 921.05 & 499.97 & 811.27 \\
\hline SA 1 & 11377.51 & 9722.45 & 1211.91 & 921.05 & 499.97 & 811.27 \\
\hline SA 2 & 10120.20 & 10120.27 & 1211.91 & 921.05 & 499.97 & 811.27 \\
\hline SA 3 & 5060.10 & 10120.27 & 1211.91 & 921.05 & 499.97 & 811.27 \\
\hline SA 4 & 15180.29 & 10120.27 & 1211.91 & 921.05 & 499.97 & 811.27 \\
\hline SA 5 & 11377.51 & 7829.31 & 1211.91 & 921.05 & 499.97 & 811.27 \\
\hline SA 6 & 11377.51 & 9052.64 & 1211.91 & 921.05 & 499.97 & 811.27 \\
\hline SA 7 & 11377.51 & 8896.94 & 1211.91 & 921.05 & 499.97 & 811.27 \\
\hline SA 8 & 10392.60 & 10120.27 & 1211.91 & 921.05 & 636.31 & 811.27 \\
\hline SA 9 & 11377.51 & 10208.35 & 1211.91 & 921.05 & 499.97 & 928.25 \\
\hline SA 10 & 11377.51 & 10031.30 & 1211.91 & 921.05 & 499.97 & 693.11 \\
\hline SA 11 & 11377.51 & 9037.54 & 1211.91 & 921.05 & 499.97 & 811.27 \\
\hline SA 12 & 11377.51 & 10120.27 & 1211.91 & 605.96 & 499.97 & 811.27 \\
\hline SA 13 & 11377.51 & 10120.27 & 1211.91 & 921.05 & 449.98 & 730.14 \\
\hline SA 14 & 11377.51 & 10120.27 & 1211.91 & 921.05 & 549.97 & 892.40 \\
\hline SA 15 & 11377.51 & 8839.83 & 1211.91 & 921.05 & 499.97 & 811.27 \\
\hline
\end{tabular}

SA, sensitivity analysis.

Table 10. Base case and sensitivity analysis results. Per-response cost of treatment with eltrombopag and rituximab. 


\begin{tabular}{|c|c|c|c|}
\hline & & \multicolumn{2}{|c|}{ Cost per response $(€)$} \\
\hline & & Eltrombopag & Rituximab \\
\hline $\begin{array}{l}\text { BASE } \\
\text { CASE }\end{array}$ & & 14732.65 & 18964.15 \\
\hline SA 1 & Body surface & 14732.65 & 18327.63 \\
\hline SA 2 & Eltrombopag dose $25 \mathrm{mg} /$ day & 7622.14 & 18964.15 \\
\hline SA 3 & Eltrombopag dose $50 \mathrm{mg} /$ day & 13317.49 & 18964.15 \\
\hline SA 4 & Eltrombopag dose $75 \mathrm{mg} /$ day & 19012.84 & 18964.15 \\
\hline SA 5 & No re-treatment with rituximab & 14732.65 & 15298.61 \\
\hline SA 6 & $\begin{array}{l}\text { Re-treatment with rituximab only for responding } \\
\text { patients }\end{array}$ & 14732.65 & 17255.94 \\
\hline SA 7 & $\begin{array}{l}\text { Re-treatment with rituximab only for non-responding } \\
\text { patients }\end{array}$ & 14732.65 & 17006.83 \\
\hline SA 8 & Decrease in eltrombopag efficacy (CR patients) & 13777.55 & 18964.15 \\
\hline SA 9 & Rituximab efficacy lower CI threshold & 14732.65 & 19292.24 \\
\hline SA 10 & Rituximab efficacy higher CI threshold & 14732.65 & 18632.75 \\
\hline SA 11 & $\begin{array}{l}\text { Rituximab administration }=\text { specialist consultation } \\
\text { cost }\end{array}$ & 14732.65 & 17231.79 \\
\hline SA 12 & Monitoring decrease in rituximab & 14732.65 & 18460.00 \\
\hline SA 13 & Decrease bleeding costs $(-10 \%)$ & 14676.38 & 18834.35 \\
\hline SA 14 & Increase bleeding costs $(+10 \%)$ & 14788.93 & 19093.96 \\
\hline SA 15 & Rituximab, truxima price & 14732.65 & 16915.45 \\
\hline
\end{tabular}

CR, complete response. CI, confidence interval; SA, sensitivity analysis.

\section{Figures}


Figure 1

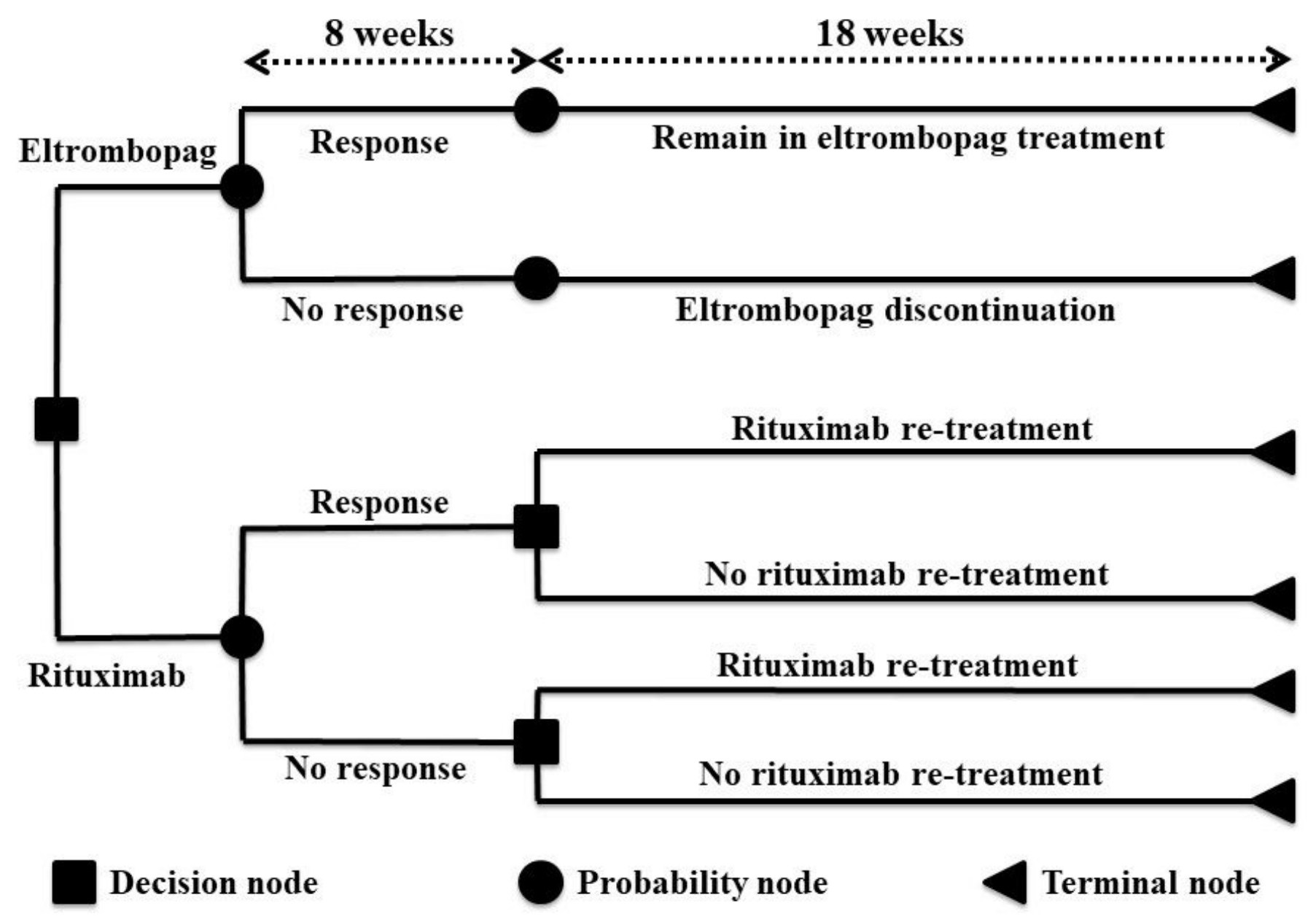

Figure 1

Model structure. Decision flow.

\section{Supplementary Files}

This is a list of supplementary files associated with this preprint. Click to download.

- Additionalfile1.docx

- Additionalfile2.docx 